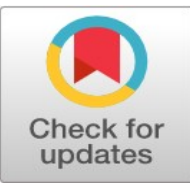

PRIMARY RESEARCH

\title{
Qualitative longitudinal research on Lithuanian student migration
}

\author{
Egidija Ramanauskaite ${ }^{1 *}$, J. Rimas Vaisnys ${ }^{2}$
}

1 Vytautas Magnus University, Kaunas, LT

2 Yale University, New Haven, CT.

\section{Keywords}

Lithuanian students

Migration

Qualitative longitudinal research

\begin{abstract}
The purpose of this study is to identify important social factors which influence students in choosing between foreign and Lithuanian universities for a college education. The research used a longitudinal study approach, where the same respondent is repeatedly observed over several time instances. A system theory approach was applied for data gathering and analysis. This was done by identifying state and the environmental values and their interactions in terms of which the student's observed behavior can be explained. Data were gathered by observing students' surroundings at their universities, semi-structured interviews with study participants, and structured questionnaires. Fifty students, some of whom have emigrated for studies in Great Britain and others who have stayed in Lithuania, have been followed by our team for almost five years. The research identified significant changes with time in the values and importance of variables characterizing the students, finding a greater than anticipated influence of peers and personal contacts on the behavior of the research participants. In contrast, economic considerations seem to have been of less significance than anticipated in modulating the behavior of both kinds of students. The study makes it possible to understand how the environments could be changed to choose studies at Lithuanian universities or return to Lithuania after graduating. This knowledge may be useful for policymakers at various levels of the education system.
\end{abstract}

Received: 14 April 2016

Accepted: 14 June 2017

Published: 21 August 2017
(C) 2017 The Author(s). Published by TAF Publishing.

\begin{abstract}
INTRODUCTION
The preferred survey methodology to characterize a society uses a small number of clear and well-defined questions and a respondent sample that is as large as possible. Such an approach can characterize the current average state of a society well but often does not provide much insight into mechanisms associated with social change processes and, consequently, can be a poor predictor of future developments. Longitudinal studies, when the same respondents are studied over a period of time (Elliott et al., 2009), can provide needed missing information but are much more difficult to carry out with respondents in mobile human societies. The inevitable drop in sample size is a great handicap but may be balanced by the possibility of turning up new and unanticipated variables that are germane to the situation, particularly if the question set is suitably enlarged. To evaluate the
\end{abstract}

\footnotetext{
* Corresponding author: Egidija Ramanauskaite

†Email: egidija.ramanauskaite@gmail.com
} 
benefits and costs associated with realistic longitudinal studies, we have studied the migration behavior of Lithuanian college students between domestic and foreign educational institutions.

Longitudinal research based on system theory approach makes it possible to perform the study more systematically, to discover deeper processes, and to reveal causal relationships. The research introduces new interrelated state and environmental variables to characterize the research system (an individual in our case). Such variables are also used in other longitudinal studies, but not in coordination and without interrelations with each other. A longitudinal study provides predictive capabilities in the time dimension, and a system approach gives results which contribute to understanding how to influence the processes. The research has practical benefits because knowing the environments and influences that encourage students to leave, it is possible to find ways to change the environments and motivate students to stay in Lithuania or to return to it. Much of the information collected in such an investigation should be of interest not only to demographers but also to the educational system as a whole.

\section{LITERATURE REVIEW}

Many of the research papers on migration are focused on the problems of 'brain drain'. For example, authors of the report of the Lithuanian Public Policy and Management Institute, "Decreasing brain drain and brain gain" (Public Policy and Institute of Management, 2007), mentioned that "emigration in recent times has become one of the most pressing threats to the long-term development of Lithuanian society and economy". Authors highlighted interrelated variables in Lithuania's highly-skilled migration such as "professional attraction in foreign countries, socioeconomic conditions having mostly push effects, state academic system and collaboration manifesting itself both in push and pull effects, and state macroeconomic conditions and governmental policy showing mostly migrants' discontent with the general situation of Lithuania".

Investigators of Lithuania 'brain drain' (e.g., Bagdanavičius and Jodkonienė, 2008; Daugeliene and Marcinkevičienė, 2009; Glinskienė and Petuškienè, 2009; Juceviciene et al., 2004; Kazlauskienè and Rinkevičius, 2006; Labanauskas, 2006) discuss the loss of skilled professionals in various areas, and find that research on student migration is no less important because they create preconditions for the 'brain drain'.

Mihi-Ramirez and Kumpikaite (2014) surveyed 1250 students from Austria, Czech Republic, France, Germany, Hungary, Lithuania, Poland, Portugal, Slovakia, Spain, Turkey, and the United Kingdom. It was found that migration decision by students "are associated with economic reasons in the most cases, such as bigger salary expectations (70 percent), better job (23 percent), and less living costs ( 7 percent)".

Economic factors also dominate in many other studies. For example, Aidis and Krupickaitè (2007) surveyed 2394 students from the main Lithuanian universities. According to the authors, "more than $30 \%$ of Lithuanian university students have plans to emigrate looking for a job after graduation. A desire to earn more than in Lithuania was indicated as the primary cause of emigration. Other reasons were self-realization, a willingness to obtain professional experience, and a desire to learn the English language" (Aidis and Krupickaitė, 2007).

Smaller-scale studies also reveal more different variables. For example, the research of 272 graduates of Management and Business Administration in Panevezys higher school (2007/2008), performed by Repeckiene et al., (2009) highlighted factors determining students decisions to leave Lithuania. As per the authors, "cultural-political and professional 
causes (...) are most significant (40 percent of variance) compared to other causes i.e., economic (15 percent), personal (9.3 percent), family ( 7.7 percent) and marital (6.2 per cent)" (Repeckiene et al., 2009). Didžgalvytė and Pukelienè (2010) interviewed 204 students who graduated in bachelor's and master's degree programs at Lithuanian universities and entered master's or doctoral degree programs abroad. "Even $74 \%$ of respondents said that the most important reason for leaving was that they discovered the appropriate study program". Other factors are "a favorable admission to studies (69.5\%), the best scholarship/financial aid (67\%), and better employment opportunities (58.5\%)". The prestige of the institution, lower costs, a desirable place, contacts with other contemporaries, and possibility of close communication with a spouse are also mentioned as significant factors to choose studies abroad (Didžgalvytė and Pukelienė, 2010).

Researchers distinguish economic, socio-cultural, professional, political, and personal motives influencing Lithuanian students' choice to emigrate (Kvedaraite et al., 2011), as well as willingness to gain experience, to learn a foreign language, and to experience adventures (Matulionis et al., 2010). Similar variables are also provided by researchers from other countries. For example, exploring the possibility of Turkish students to return to Turkey after graduation, Gungor and Tansel (2008) found that economic reasons (higher salaries) and lifestyle preferences keep them from returning. Family considerations influence their decision to come back to Turkey or to stay abroad. It is noted that participation in a Turkish Student Association also increases intentions to return. Rajan and Wadhawan (2014) collected data from 112 prospective Indian students, who applied "for student visas to the UK across five cities in India in 2012". Authors conclude, that "many Indians who go abroad for higher education also seek employment opportunities outside India. It is, therefore, a combination of attaining quality education in addition to employment opportunities which result in more Indians going to the US or the UK for higher education" (Rajan and Wadhawan, 2014). "Economic and professional factors typically act as strong incentives (for foreign students) to stay in the US, while personal and societal factors tend to draw students back to their home countries. In the long run, a natural progression of professional and personal decisions leads many to become permanent immigrants" (Hazen and Alberts, 2006).

The research described in our report about a migration of Lithuanian university students has been based on longitudinal data collection and the presence of the time dimension is a significant innovation relative to the prior work reviewed above. The identification of several additional variables reflecting personal expectations of the respondents is not so surprising, given the work e.g., of Kromkowski (1986), but is also a contribution to a more nuanced understanding of student migration processes and should generalize to other migrations as well.

\section{THEORY AND METHODOLOGY}

This investigation is being done in a framework of social group theory and of dynamical system theory. The first suggests that persons in a social group react to the presence of others in creating their cultural identity, viewpoints, and values (Forsyth, 2010; Postmes et al., 2005). The second provides a formal framework for organizing the observational data in terms of systems, environments and their interactions so that causal relationships may become more evident (Luenberger, 1979; Ramanauskaite and Vaisnys, 2015; Vaisnys et al., 2010). In this investigation, each student (respondent) is viewed as a system. The social environment for this system consists of other persons or groups that influence a given student's behavior, which is deemed to depend on both the 
nature of the environment and the student's internal state. The aim of the research is to identify the state and the environmental variables in terms of which the system's (here the student's) observed behavior can be explained. Operationally, this means that the individual elements making up each of the variables must be identified and the coupling between elements of different variables must be characterized. In this investigation, the ultimate variable of interest is that for describing the decision state of the student, consisting of the elements 'to stay' or 'not to stay'. To explain how or when a given element is established, one needs to describe and determine the elements associated with a multitude of variables ranging from those that describe 'attractiveness of program', 'quality of program', and student-tutor interactions' to those such as 'study major', 'extent of workstudy practice' or 'financial grants', and many others in between. Not the least, in terms of both influence on the behavior under attempted explanation and on the difficulty in assessing and evaluating them, are variables that describe how the given student (our system) interacts with other students (a significant part of our system's social environment).

\section{Selection of Study Participants}

Five groups of students were selected for this research: a) ten graduates of high schools and b) ten first-level university graduates (BA), both groups studying at foreign universities, mostly in Great Britain; c) ten high school graduates and d) ten first level university graduates (BA), both groups studying at Lithuanian universities and, finally, e) ten Lithuanian students who graduated from foreign universities and then decided to return home and continue their educations in Lithuania. All study participants were recruited by using the 'snowball methodology' for each of the groups, e.g., the initial respondent, identified by a teacher in a high school, suggested other possible participants who, in turn, proposed still others until the desired group size was reached.

As the investigation progressed over the five sampling periods and information was collected and analyzed, there were six recurring patterns in students behavior found. We chose one representative of each behavior pattern and reviewed in close detail the information about that respondent, not only as provided by the questionnaires but also that from the in-depth interviews.

The Cases Selected for the Analysis Included:

R11-student who, after graduating high school, went to study at Cambridge, then continued his studies in Edinburgh and went on to study in the U.S. (not planning to return to Lithuania).

R6-student who, after graduating high school, went to study at Cambridge University and after graduating, returned to Lithuania to work.

R2-student who, after graduating high school in Lithuania, went to study at Glasgow University (GB) and after graduating, found a job in Glasgow.

R30-student who started to study in Lithuania and after a year gave up her studies and went to work in GB.

R28-student who, after graduating high school, stayed to study at a Lithuanian university and after graduating, started to work.

R33-student who, after graduating the first level of university studies (BA), continued to study in an MA program at the same Lithuanian university and currently is studying in the Ph.D. program.

\section{Research Stages}

The research has been continuing for five years and covers five time instances. It started (marked as $\mathrm{t} 0$ ) when students chose their future studies. The research continued ( $\mathrm{t} 1$ ) after 
students had already studied 1.5 months in their programs. The next stage of the research was performed a year later ( $\mathrm{t} 2$ ) after they had already adapted to a new academic environment. Then the research was repeated after two years when the students had started the fourth year of their education ( $\mathrm{t} 3$ ), and some of them had already started their work activities. The last stage of the research ( $\mathrm{t} 4$ ) was performed a year later when some of the students had either graduated their universities or started their Ph.D. studies. Some students who had studied at foreign universities continued to reside abroad, while others returned to Lithuania. Some who had studied at Lithuanian universities continued to reside in Lithuania, while others have gone to other countries.

\section{Data Gathering Methods}

Data were gathered during face-to-face and Skype semi-structured interviews as well as email using structured questionnaires that consisted of approximately 400 questions. The raw data structure is presented on Excel sheets and expressed in numerical values with extensive comments elaborating them. Other significant data consist of transcribed interviews.

Many empirical variables were identified at the start of the investigation ( $t 0$ ) from the in-depth interviews; the effort during these interviews was to discern the motivation of the respondents for the choices they had made regarding where to study, at home or abroad. For example, almost all respondents stated that they chose studying at a foreign university because the quality of the education will be superior to that provided at home. Similarly, almost all respondents stated that their fellow students, who were also choosing studies abroad, strongly influenced their choice. More variability appeared concerning availability of work-study possibilities, free or low-cost educational programs, independence from parents, post-degree employment, foreign travel opportunities, and variety of cultural experiences. Variables were included to describe economic factors, even though students themselves did not initially indicate that these factors might be significant. At the next phase of the investigation ( $\mathrm{t} 1 \mathrm{a}$ month and a half later), the questionnaire was modified for use in later stages to reflect the information found in the t0 stage in-depth interviews. It tested the effect of the modification by comparing the $\mathrm{t} 0$ and $\mathrm{t} 1$ responses from the same respondents.

It is the qualitative data (texts of semi-structured interviews) that produce the significant new information about the behavior of students, so that traditional statistical techniques are not really applicable, but these same data do provide directions for future quantitative studies when such techniques would be profitably employed. Data tables displaying the time-dependent behavior of the individual respondents are deemed to be the most suitable for presentation and further planning.

\section{RESEARCH MODEL \\ Description of Variables}

State variables and values: State variable s1-location of study:

L-Lithuania and F-Foreign country

State variable s2-quality of education (including the desired degree program):

3-good, 2-at an average, 1-bad and 0-no opinion

State variable s11-social integration:

3-easy to communicate, 2-some troubles with communication,

1 -feeling of a language and/or a cultural barrier while communicating with the commu-

nity and 0 -no opinion

State variable s13-employment prospects after graduating: 
3-I hope that after graduating I will be able to get a job in that country, 2-sometimes I think about that, 1-that does not matter and 0-no opinion

State variable s15-material living conditions:

3-I care about good living conditions, 2-this is an average priority, 1-this is not a criterion and 0-no opinion

State variable s16-financial well-being:

3-I feel good financially, 2-at an average, 1-I feel bad and 0-no opinion

Environmental influence variables and values: Environmental variable u6-motivating students:

3-my classmates are motivated, 2-at an average, 1-my classmates are not motivated and 0 -no opinion

Environmental variable u1-advising friends:

3-my classmates/peers are my advisors when choosing studies, 2-at an average and 1-no, they do not influence my decisions

Environmental variable u2-girlfriend/boyfriend:

3-she/he influences my decision to stay in Lithuania or to leave or return to Lithuania, 2-at an average, 1-no, she/he does not influence my decisions and 0-inapplicable

Environmental variable u3-advising parents:

3-they influence my choice of a place to study, 2-at an average, 1-no, they do not influence my decisions and 0-no opinion

Environmental variable u5-motivating teachers:

3-my teachers are enthusiastic, qualified and prepare us well, 2-at an average, 1-no, they are not qualified and 0 -no opinion

Environmental variable u5-teacher advisors:

3-my teachers advised me on choosing a university, 2-a little advice, 1-no, they did not advise me and 0-no opinion

Environmental variable u14-university encouraging student employment:

3-university provides conditions for students to work (flexible schedules, advisors)

2-at an average, 1-no, the university does not tolerate working students, n/a-not applicable

Environmental variable u69-income per month:

$\mathrm{A}-=€ 0-144, \mathrm{~B}-€ 145-579, \mathrm{C}-€ 580-1449$ and $\mathrm{D}-€ 1450$ and more (all incomes measured by the euro)

Environmental variable u95-university degree program/affiliation (the figures refer to the student identification number):

Vilnius High School 11, Cambridge BA 11, Edinburgh MA 11, Berkeley Ph.D. 11, Kaunas High School 6, Cambridge BA 6, Cambridge MA 6, Vilnius start-up 6, Kaunas High School 2, Glasgow BA 2, Glasgow BA 2.1, Glasgow start-up 2, Kedainiai High School 30, Kaunas University BA 30, company for sorting goods in London 30, post office in London 30, Kaunas High School 28, Kaunas University BA 28, Kaunas Pharmacy 28, Kaunas University BA 33, Kaunas University MA 33 and Kaunas University Ph.D. 33

\section{Data Tables}

Variables and associated values appear in the tables below. There is a table for each individual case (student). Tables 1, 2 and 3 represent the data of students who went abroad, and tables 4, 5 and 6 represent the data of students who remained in Lithuania at the initial time ( $\mathrm{t} 0)$.

The first row of a table indicates the state variables of students [s1-s16] and the environmental influence variables [u6-u95]. The first left column indicates the periods of time 
$(\mathrm{t} 0, \mathrm{t} 1, \mathrm{t} 2, \mathrm{t} 3$ and $\mathrm{t} 4)$ when the data were gathered. The corresponding values of variables in a particular moment of time are marked in the cells of the tables. The comparison of one row with the other shows changes over time. The variables characteristics of each student are included in the table of each other student for verification.

TABLE 1. Students who went to Great Britain: R11

\begin{tabular}{llllllllllllllll}
\hline \hline $\mathrm{t}$ & $\mathrm{s} 1$ & $\mathrm{~s} 2$ & $\mathrm{~s} 11$ & $\mathrm{~s} 13$ & $\mathrm{~s} 15$ & $\mathrm{~s} 16$ & $\mathrm{u} 6$ & $\mathrm{u} 1$ & $\mathrm{u} 2$ & $\mathrm{u} 3$ & $\mathrm{u} 5$ & $\mathrm{u} 4$ & $\mathrm{u} 14$ & $\mathrm{u} 69$ & $\mathrm{u} 95$ \\
\hline $\mathrm{t} 0$ & $\mathrm{~L}$ & 3 & 3 & 2 & 1 & 3 & 3 & 3 & 1 & 2 & 3 & 2 & 1 & $\mathrm{~A}$ & Vilnius high school 11 \\
$\mathrm{t} 1$ & $\mathrm{~F}$ & 2 & 1 & 1 & 3 & 2 & 3 & 3 & 1 & 2 & 2 & 1 & 1 & $\mathrm{~A}$ & Cambridge BA 11 \\
$\mathrm{t} 2$ & $\mathrm{~F}$ & 2 & 1 & 1 & 3 & 2 & 3 & 3 & 1 & 2 & 2 & 1 & 1 & $\mathrm{~A}$ & Cambridge BA 11 \\
$\mathrm{t} 3$ & $\mathrm{~F}$ & 3 & 2 & 1 & 1 & 1 & 2 & 2 & 1 & 2 & 3 & 1 & 1 & $\mathrm{~A}$ & Edinburgh MA 11 \\
$\mathrm{t} 4$ & $\mathrm{~F}$ & 3 & 0 & 1 & 1 & 1 & 3 & 3 & 1 & 0 & 3 & 1 & 1 & $\mathrm{C}$ & Berkeley Ph.D. 11 \\
\hline \hline
\end{tabular}

TABLE 2 . Students who went to Great Britain: R6

\begin{tabular}{llllllllllllllll}
\hline \hline $\mathrm{t}$ & $\mathrm{s} 1$ & $\mathrm{~s} 2$ & $\mathrm{~s} 11$ & $\mathrm{~s} 13$ & $\mathrm{~s} 15$ & $\mathrm{~s} 16$ & $\mathrm{u} 6$ & $\mathrm{u} 1$ & $\mathrm{u} 2$ & $\mathrm{u} 3$ & $\mathrm{u} 5$ & $\mathrm{u} 4$ & $\mathrm{u} 14$ & $\mathrm{u} 69$ & $\mathrm{u} 95$ \\
\hline $\mathrm{t} 0$ & $\mathrm{~L}$ & 3 & 2 & 1 & 1 & 3 & 3 & 3 & 1 & 2 & 3 & 1 & 1 & $\mathrm{~B}$ & Kaunas high school 6 \\
$\mathrm{t} 1$ & $\mathrm{~F}$ & 3 & 1 & 1 & 1 & 3 & 3 & 3 & 1 & 2 & 3 & 1 & 1 & $\mathrm{C}$ & Cambridge BA 6 \\
$\mathrm{t} 2$ & $\mathrm{~F}$ & 3 & 1 & 1 & 1 & 3 & 3 & 3 & 1 & 2 & 3 & 1 & 1 & $\mathrm{C}$ & Cambridge BA 6 \\
$\mathrm{t} 3$ & $\mathrm{~F}$ & 3 & 1 & 1 & 1 & 3 & 3 & 3 & 1 & 1 & 3 & 2 & 1 & $\mathrm{C}$ & Cambridge MA 6 \\
$\mathrm{t} 4$ & $\mathrm{~L}$ & 3 & 3 & 1 & 1 & 3 & 3 & 2 & 2 & 1 & 3 & 1 & 1 & $\mathrm{C}$ & Vilnius start-up 6 \\
\hline \hline
\end{tabular}

TABLE 3 . Students who went to Great Britain: R2

\begin{tabular}{llllllllllllllll}
\hline \hline $\mathrm{t}$ & $\mathrm{s} 1$ & $\mathrm{~s} 2$ & $\mathrm{~s} 11$ & $\mathrm{~s} 13$ & $\mathrm{~s} 15$ & $\mathrm{~s} 16$ & $\mathrm{u} 6$ & $\mathrm{u} 1$ & $\mathrm{u} 2$ & $\mathrm{u} 3$ & $\mathrm{u} 5$ & $\mathrm{u} 4$ & $\mathrm{u} 14$ & $\mathrm{u} 69$ & $\mathrm{u} 95$ \\
\hline $\mathrm{t} 0$ & $\mathrm{~L}$ & 3 & 2 & 1 & 3 & 2 & 3 & 3 & 1 & 1 & 3 & 3 & 3 & $\mathrm{~A}$ & Kaunas high school 2 \\
$\mathrm{t} 1$ & $\mathrm{~F}$ & 2 & 1 & 1 & 2 & 1 & 3 & 3 & 1 & 1 & 3 & 3 & 1 & $\mathrm{~B}$ & Glasgow BA 2 \\
$\mathrm{t} 2$ & $\mathrm{~F}$ & 1 & 1 & 0 & 3 & 3 & 3 & 3 & 1 & 3 & 3 & 3 & 3 & $\mathrm{~B}$ & Glasgow BA 2 \\
$\mathrm{t} 3$ & $\mathrm{~F}$ & 3 & 3 & 3 & 3 & 1 & 3 & 3 & 3 & 2 & 3 & 3 & 3 & $\mathrm{~B}$ & Glasgow BA 2.1 \\
$\mathrm{t} 4$ & $\mathrm{~F}$ & 2 & 3 & 1 & 1 & 3 & 1 & 1 & 3 & 1 & 2 & 1 & 3 & $\mathrm{C}$ & Glasgow start-up 2 \\
\hline \hline
\end{tabular}

TABLE 4. Students who remained in Lithuania: R30

\begin{tabular}{llllllllllllllll}
\hline \hline $\mathrm{t}$ & $\mathrm{s} 1$ & $\mathrm{~s} 2$ & $\mathrm{~s} 11$ & $\mathrm{~s} 13$ & $\mathrm{~s} 15$ & $\mathrm{~s} 16$ & $\mathrm{u} 6$ & $\mathrm{u} 1$ & $\mathrm{u} 2$ & $\mathrm{u} 3$ & $\mathrm{u} 5$ & $\mathrm{u} 4$ & $\mathrm{u} 14$ & $\mathrm{u} 69$ & $\mathrm{u} 95$ \\
\hline $\mathrm{t} 0$ & $\mathrm{~L}$ & 3 & 1 & 3 & 1 & 3 & 3 & 2 & 3 & 3 & 3 & 1 & 3 & B & Kedainiai high sch. 30 \\
$\mathrm{t} 1$ & $\mathrm{~L}$ & 3 & 1 & 3 & 1 & 3 & 3 & 2 & 3 & 3 & 3 & 1 & 3 & $\mathrm{~B}$ & Kaunas Univ. BA 30 \\
$\mathrm{t} 2$ & $\mathrm{~L}$ & 2 & 1 & 3 & 1 & 1 & 2 & 3 & 3 & 1 & 3 & 1 & 1 & $\mathrm{~B}$ & Kaunas Univ. BA 30 \\
$\mathrm{t} 3$ & $\mathrm{~F}$ & 1 & 0 & 1 & 3 & 2 & 0 & 3 & 1 & 2 & 0 & 1 & n/a & D & Company in London 30 \\
$\mathrm{t} 4$ & $\mathrm{~F}$ & 3 & 2 & 2 & 3 & 3 & 3 & 2 & 3 & 3 & 3 & 1 & n/a & D & Post office in London 30 \\
\hline \hline
\end{tabular}

TABLE 5 . Students who remained in Lithuania: R28

\begin{tabular}{llllllllllllllll}
\hline \hline $\mathrm{t}$ & $\mathrm{s} 1$ & $\mathrm{~s} 2$ & $\mathrm{~s} 11$ & $\mathrm{~s} 13$ & $\mathrm{~s} 15$ & $\mathrm{~s} 16$ & $\mathrm{u} 6$ & $\mathrm{u} 1$ & $\mathrm{u} 2$ & $\mathrm{u} 3$ & $\mathrm{u} 5$ & $\mathrm{u} 4$ & $\mathrm{u} 14$ & $\mathrm{u} 69$ & $\mathrm{u} 95$ \\
\hline t0 & $\mathrm{L}$ & 3 & 3 & 3 & 3 & 3 & 2 & 1 & 3 & 3 & 2 & 1 & 1 & $\mathrm{~A}$ & Kaunas high school 28 \\
t1 & $\mathrm{L}$ & 3 & 3 & 3 & 3 & 3 & 2 & 1 & 3 & 3 & 2 & 1 & 1 & $\mathrm{~A}$ & Kaunas Univ. BA 28 \\
t2 & $\mathrm{L}$ & 3 & 3 & 3 & 3 & 3 & 2 & 1 & 3 & 3 & 2 & 1 & 1 & $\mathrm{~A}$ & Kaunas Univ. BA 28 \\
t3 & $\mathrm{L}$ & 1 & 3 & 1 & 1 & 2 & 2 & 1 & 3 & 3 & 2 & 3 & 1 & B & Kaunas Univ. BA 28 \\
t4 & $\mathrm{L}$ & 2 & 3 & 1 & 1 & 3 & 3 & 1 & 1 & 3 & 3 & 1 & 1 & $\mathrm{~B}$ & Kaunas pharmacy 28 \\
\hline \hline
\end{tabular}


TABLE 6 . Students who remained in Lithuania: R33

\begin{tabular}{llllllllllllllll}
\hline \hline $\mathrm{t}$ & $\mathrm{s} 1$ & $\mathrm{~s} 2$ & $\mathrm{~s} 11$ & $\mathrm{~s} 13$ & $\mathrm{~s} 15$ & $\mathrm{~s} 16$ & $\mathrm{u} 6$ & $\mathrm{u} 1$ & $\mathrm{u} 2$ & $\mathrm{u} 3$ & $\mathrm{u} 5$ & $\mathrm{u} 4$ & $\mathrm{u} 14$ & $\mathrm{u} 69$ & $\mathrm{u} 95$ \\
\hline $\mathrm{t} 0$ & $\mathrm{~L}$ & 3 & 3 & 3 & 1 & 1 & 1 & 1 & 1 & 3 & 3 & 1 & 1 & $\mathrm{~A}$ & Kaunas Univ. BA 33 \\
$\mathrm{t} 1$ & $\mathrm{~L}$ & 2 & 3 & 3 & 1 & 1 & 1 & 1 & 3 & 3 & 3 & 3 & 1 & $\mathrm{~A}$ & Kaunas Univ. MA 33 \\
$\mathrm{t} 2$ & $\mathrm{~L}$ & 1 & 3 & 3 & 1 & 1 & 1 & 1 & 3 & 3 & 2 & 1 & 1 & $\mathrm{~A}$ & Kaunas Univ. MA 33 \\
$\mathrm{t} 3$ & $\mathrm{~L}$ & 1 & 3 & 1 & 1 & 3 & 1 & 1 & 2 & 1 & 1 & 1 & 1 & $\mathrm{~B}$ & Kaunas Univ. Ph.D. 33 \\
$\mathrm{t} 4$ & $\mathrm{~L}$ & 1 & 3 & 1 & 1 & 3 & 1 & 1 & 3 & 1 & 1 & 1 & 3 & $\mathrm{C}$ & Kaunas Univ. Ph.D. 33 \\
\hline \hline
\end{tabular}

\section{DATA ANALYSIS}

An example of the values explored to facilitate 'reading' the table is presented below. The first row in the table 1 shows the values of state variables (marked as 's') and the values of environmental influence variables (marked as ' $u$ ') at the initial period of time ( $t 0$ ), when the student chose a university for future education.

\section{States (s1-s16):}

s1 (t0)-high school student in Lithuania (value L)

s2 (t0)-studies selected abroad, because the quality of the studies there is better than it is in Lithuania (value 3)

s11 (t0)-there is a good social environment in Lithuania and expects the same abroad (value 3)

s13 (t0)-does not exclude a chance to gain employment in Great Britain after studies are over (value 2)

s15 (t0)-does not link leaving to study abroad with better economic conditions and does not believe students care about this (value 1)

s16 (t0)-feels financially fine living in Lithuania (with parents) (value 3)

\section{Environmental influences (u6-u95):}

u6 (t0)-the student's close environment consists of other high school students who are good learners and motivating for studies (value 3 )

u1 (t0)-fellow classmates encourage her to go to Cambridge for studies, because the quality of studies is better there than it is at Lithuania's universities (value 3)

$\mathrm{u} 2(\mathrm{t} 0$ )-there is no boyfriend to follow (value 1 )

u3 (t0)-the student does not notice any great parental incentive to leave for studies abroad (value 2)

u5 (t0)-notices teachers who are motivational for good studies (value 3)

$\mathrm{u} 4$ ( $\mathrm{t} 0$ )-teachers do not directly encourage a choice for studying abroad (value 2)

$\mathrm{u} 14$ (t0)-the choice is for Cambridge University, which disapproves of student employment (value 1) (however, it provides a scholarship, and it is possible to get a student loan)

u69 (t0)-financial income is denoted as A, i.e., €0-58 per month (receives parental support financially and housing with them)

u95 (t0)-the student's study environment is Vilnius High School 11, which is one of the best schools in Lithuania

\section{Value Changes Over Time}

By reading one row after another $(\mathrm{t} 0, \mathrm{t} 1, \mathrm{t} 2, \mathrm{t} 3, \mathrm{t} 4)$, it can be seen that some values change over time, while others remain unchanged. It was noticed, for example, that one characteristic common to both students who are leaving and students who have chosen studies 
in Lithuania is that they do not gather sufficient information about their future studies. Thereby their state $\mathrm{s} 2(\mathrm{t} 0$ ) crosses over to $\mathrm{s} 2$ (t1)-it changes to the less optimistic (e.g., as shown in Tables 1, 3 and 6).

Characteristic of students who are leaving is that they do not gather sufficient information about cultural differences. Thereby their state s11 (t0) crosses over to s11 (t1) (e.g., as shown by Tables 1, 2 and 3)-they experience difficulties in their interactions.

Students also do not assess their earning possibilities abroad sufficiently. Thereby their state s15 (t0) crosses over to s15 (t1) (e.g., as shown by Table 3)-they realize that their earning possibilities are not as they had expected. The students who lack funds for their living expenses learn from their friends which universities approve of employment while studying when they are selecting where to study u14 (t0) (e.g., Table 3) and make their choice accordingly. However, upon arrival for studies, they see that the environment is different than they expected. The university might not disapprove of student employment; however, it does not advise where and how to get a job-u14 (t1). Due to the influence of a changed environment, the financial state of this student $\mathrm{s} 16$ ( $\mathrm{t} 0$ ) crosses over to $\mathrm{s} 16$ ( $\mathrm{t} 1$ )-it becomes considerably worse. In case the student studying in Lithuania loses his/her financial source (e.g., parental support) and must provide earnings for studying and living, his/her state s1 (t2) crosses over to s1 (t3) (e.g., as shown by Table 4)-this student goes abroad to work (because it would be difficult to earn enough in Lithuania due to the low pay scales).

\section{Comparison of the Environments of Students Leaving Lithuania and those Remaining}

The students who are leaving see a motivational environment of their classmates/other students u6 ( $\mathrm{t} 0-\mathrm{t} 4)$, which influences their viewpoints and decisions regarding a choice for studies $\mathrm{u} 1(\mathrm{t} 0-\mathrm{t} 4)$. These students are less inclined to notice parental inducements for studying abroad $\mathrm{u} 3$ (t0-t4) (e.g., as shown by the first three Tables 1, 2 and 3).

Meanwhile the students who are remaining in Lithuania see less of a motivated environment of their age contemporaries u6 ( $\mathrm{t} 0-\mathrm{t} 4)$, which either influences them less or not at all $\mathrm{u} 1(\mathrm{t} 0-\mathrm{t} 4)$. However, these students see more parental inducements to study and, afterwards, work in Lithuania u3 (t0-t4) (e.g., as shown by students studying in Lithuania in Tables 4, 5 and 6).

An important environmental influence for students consists of their boyfriends/ girlfriends who determine their ultimate decision to return to Lithuania after their studies abroad, e.g., u2 (t4) in Table 2; to remain living abroad, e.g., u2 (t4) Table 3, or select studies in Lithuania u2 (t0) even during later stages, as shown by Tables 4, 5 and 6.

Both the leaving and the remaining students mostly see an environment consisting of good teachers u 5 ( $\mathrm{t} 0-\mathrm{t} 3$ ). However, students of both categories see few inducements from teachers relevant to their choice for a study location $\mathrm{u} 4$ ( $\mathrm{t} 0-\mathrm{t} 3$ ) (by the $\mathrm{t} 4$ stage, most students are already assessing their work environment). Students who want to study abroad but do not have sufficient financial incomes for such studies and do not want to take out a loan often see those universities that offer schedules conducive to working while studying as more suitable for themselves u14(t0) (e.g., as shown in Table 3).

\section{States Compared}

Students, both those leaving and those selecting studies in Lithuania expect good quality/good programs for their studies s2 (t0) (e.g., in all cases of students submitted). Students leaving for universities abroad do not associate their studies with future plans for employment abroad s13 (t0-t4) (Tables 1, 2 and 3) and do not plan to remain there. Mean- 
while the students proceeding with studies in Lithuania do associate their studies with future employment possibilities in Lithuania s13 (t0-t2) (e.g., as shown in Tables 4, 5 and 6).

\section{Interactions of Environments and States}

The tables can help in searching for causal connections between the influences from states and from environments. In the research process, there will be states when they change 'in and of themselves', when there is dependency on environmental influences or when there is no reaction to influences. Once the causal connections between environmental influences and states are discovered, it becomes possible to offer suggestions on how to change environments in order for as many students as possible to choose studies in Lithuania, and for those who have left, to return to Lithuania. For example, it could be complicated for universities to improve the quality of their studies in a short time. Nevertheless, they could make fast adjustments in correcting organizational matters in order to give students a chance to compile more accommodating schedules on their own and, when necessary, allocate part of their time for working.

\section{DISCUSSION}

Quantitative and qualitative longitudinal studies are useful to monitor the behavior of individuals over time, but their possibilities are different. For example, the quantitative longitudinal research on migration uses large samples of respondents and is based on statistical surveys, data from the Departments of Statistics and other archives (Constant and Massey, 2003; Klinthäll, 2003; Kodrzycki, 2001). In contrast, researchers who carry out qualitative longitudinal research can involve a small number of respondents but perform deeper research using in-depth interviews, biographical approaches and participant observations. Social researchers are often looking for ways to combine qualitative and quantitative methods in longitudinal studies (Goldenberg et al.,2001). The use of research tools from humanities and science disciplines as well as computer assisted data gathering and analysis may become an advantage.

The innovativeness of this research happens to be one of those opportunities for such a combination. What is being done differently here? (a) The dynamic systems theoretical approach for a longitudinal study as used here encourages searching for state and the environmental influence variables when gathering data and when analyzing them. (b) The tools for quantitative research (questionnaires, tables) are used here in an effort to gather data systematically. (c) The use of a qualitative research technique-in-depth interviews-is for acquiring 'insider' insights, which assist in seeing the environments of importance to a person through that person's eyes. In this case, a researcher asks the individual under study to fill out a questionnaire in short responses and performs an in-depth interview for each time stage. A useful way to format data describing an individual is using tables (numbers) with 'pockets' (texts describing their ethnographic meanings).

\section{CONCLUSION}

The research identified significant changes with time in important values and variables characterizing the behavior of students, particularly a greater than anticipated influence of peers and personal contacts on the behavior of the studied individuals. In contrast, economic considerations seem to have been of less significance than anticipated in modulating the behavior of the respondents. These generalizations hold true for both categories of students: those who chose to continue their studies in Lithuania and those who chose 
The cases represented in this article and the broader context of this research suggest that social contacts and the information gained from them influence students. Contacts with fellows of the same age are the most important to them. The life's path taken by a student depends greatly on the social circle of that student from his/her school days. If they are motivated students and have a good environment of motivating teachers and study mates, they will 'pull' one another into good universities (especially abroad), where they (in case of success) will again have a good intellectual environment and they will generate new, higher pursuits (the R11, R6 cases). The same sort of 'mechanism' can encourage those who left to return to Lithuania. So long as a small group of talented people forms in Lithuania consisting of study mates/age contemporaries with ambitious pursuits and opportunities, they will pull one another into such activities, which would encourage those who left to return to Lithuania (the R6 case). It would seem that a youth start-up opportunity is a decent engine for developing new activities and trying them out abroad as well as in Lithuania.

In the event the student is motivated for work and has age contemporaries selecting studies at universities abroad for an offered chance of employment, it is likely such a student will leave and try to get a job abroad. It is likely the latter type of student can become an economic émigré for whom studies serve as a means to entrench in the society of Great Britain (the R2 case).

A possible assumption is that students who are not fully satisfied with their selected studies at Lithuanian universities but have spent considerable amount of time pursuing them will not terminate their studies, because they have become accustomed to them, especially when family and friends in the area of residence are important to the students. Students do not want to drop out of their studies upon realizing that a considerable investment has been made into them already (the R33 case). The study provides recommendations for policy makers in higher education. In order to reduce emigration of academic youth, Lithuanian universities need to provide a stimulating study environment where groups of motivated students could grow. Among specific recommendations, we can list the desirability of creating spaces for students to initiate start-ups, in the form of joint efforts by universities and local companies. Another recommendation would be for universities to modify internal procedures so that students who are interested in work opportunities during studies can be accommodated without compromising the quality of their education or of the work experience. Public presentation of genuine, even if small, improvements in the educational system is likely to produce a positive student response.

\section{LIMITATIONS AND RECOMMENDATIONS}

Our research presented also has specific limitations, namely a small number of respondents. It is not possible to follow the behaviors of a great number of individuals with this method. Nonetheless, a systematic and, at the same time, an in-depth analysis of cases of carefully selected individuals permits making an assumption that under similar states and environmental influences other persons would behave similarly. The other limitation of this research is related to systematic data gathering. It is difficult to gather all of the data during long time instances as provided in the study design. For example, there were cases when the student did not respond at the scheduled time to participate in the particular research stage, but he/she did respond after some time. In such cases, data were collected retrospectively, and often revealed the psychological state of the student (at the scheduled time) better than an on-schedule interview would have. The third limitation is related to computer speech recognition of Lithuanian language. The Lithuanian speech recognition computer programs are not yet well developed so that researchers must transcribe the 
interview texts expending much time and resources. All these restrictions encourage researchers to search for advanced techniques for social research. We believe that computer programs developed by researchers of social sciences and humanities together with IT professionals could help to facilitate the social research process in terms of data gathering and analysis and to enhance its quality.

\section{ACKNOWLEDGMENT}

The research is sponsored by the Research Council of Lithuania, the project agreement number MIP-076/2014

\section{REFERENCES}

Aidis, Rūta, and Dovilè Krupickaitė. 2007. Jaunimo emigracijos tyrimas: Lietuvos universitetinių aukštųjų mokyklų studentų nuostatos emigruoti. Oikos: Lietuviu Migracijos ir Diasporos Studijos 3: 36-50.

Bagdanavičius, Juozas, and Zita Jodkonienè. 2008. Brain drain from Lithuania: The attitude of civil servants. Engineering Economics 2, no. 57: 55-60.

Constant, Amelie, and Douglas S. Massey. 2003. Self-selection, earnings, and out-migration: A longitudinal study of immigrnts to Germany. Journal of Population Economics 16, no. 4: 631-653. D0I: 10.1007/s00148-003-0168-8

Daugeliene, Rasa, and Rita Marcinkeviciene. 2009. Brain circulation: Theoretical considerations. Inzinerine Ekonomika En-

gineering Economics 3, no. 63: 49-57.

Didžgalvytè, Monika, and Violeta Pukelienè. 2010. Protų nutekẻjimas: Užsienyje magistrantūros ir doktorantūros studijas baigusiųų reemigracijos analizè ir vertinimas. Taikomoji Ekonomika: Sisteminiai Tyrimai 4, no. 1: 123-138.

Elliott, Jane, Janet Holland, and Rachel Thomson. 2009. Longitudinal and panel studies. In Sage handbook of social re- search methods, eds. Pertti Alasuutari, Leonard Bickman, and Julia Brannen, 228-248. London, UK: Sage Publications.

Forsyth, Donelson. R. 2010. Group dynamics. Wadsworth, OH: Wadsworth, Cengage Learning.

Glinskienė, Rasa, and Edita Petuškienè. 2009. Pasaulinès ekonominès krizės poveikis lietuvių reemigracijos ir protų nutekẻimo procesams. Ekonomika ir Vadyba 14, 763-771.

Goldenberg, Claude, Ronald Gallimore, Leslie Reese, and Helen Garnier. 2001. Cause or effect? A longitudinal study of im- migrant Latino parents' aspirations and expectations, and their children's school performance. American Educational Research Journal 38, no. 3: 547-582. D0I: 10.3102/00028312038003547

Gungor, Nil D., and Aysit Tansel. 2008. Brain drain from Turkey: An investigation of students' return intentions. Applied Economics 40, no. 23: 3069-3087.

Hazen, Helen D., and Heike C. Alberts. 2006. Visitors or immigrants? International students in the United States. Population,

Space and Place 12, no. 3: 201-216. DOI: 10.1002/psp.409

Juceviciene, PaImira, Renata Viržintaitė aite, and Giedrius Jucevicius. 2004. 'Brain drain' in country in-transition: Paradox of higher education. Socialiniai Mokslai 2, no. 44: 45-55.

Kazlauskienè, Aušra, and Leonardas Rinkevičius. 2006. Lithuanian "brain drain" causes: Push and pull factors. Engineer-

ing Economics 1, no. 46: 27-37.

Klinthäll, Martin. 2003. Return migration from Sweden 1968-1996: A longitudinal analysis. Stockholm, SE: Almqvist \& Wiksell International.

Kodrzycki, Yolanda K. 2001. Migration of recent college graduates: Evidence from the national longitudinal survey of youth.

New England Economic Review, 13-34.

Kromkowski, John A. 1986. Eastern and Southern European immigrants: Expectations, reality, and a new agenda. The

An- $\quad$ nals of the American Academy of Political and Social Science 487, no. 1: 57-78. DOI: 10.1177/0002716286487001003

Kvedaraitè, Nida, Aušra Repečkienė, Rasa Glinskienė, and Donatas Bakšys. 2011. Akademinio jaunimo migracijos patirties

tyrimas. Profesinés Studijos: Teorija ir Praktika 8, 220-226. 
Labanauskas, Liutauras. 2006. 'Protų nutekẻjimo' problema Lietuvoje: Medikų emigracija. Filosofija, Sociologija 2, 27-34. Luenberger, David. 1979. Introduction to dynamic systems. Theory, models, and applications. New York, NY: Wiley.

Matulionis, Arvydas V., Gražina Maniukaitė, Inija Trinkūnienė, Eugenija Krukauskienė, and Darius Liutikas. 2010. Lietuvos studentijos socialinio portreto bruožai. Lietuvos socialinių tyrimų centras, Vilnius, LT.

Mihi-Ramirez, Antonio, and Vilmante Kumpikaite. 2014. Economics reason of migration from point of view of students. Procedia-Social and Behavioral Sciences 109, 522-526. D0I: 10.1016/j.sbspro.2013.12.500

Postmes, Tom, Russell Spears, Antonia T. Lee, and Rosemary J. Novak. 2005. Individuality and social influence in groups: Inductive and deductive routes to group identity. Journal of Personality and Social Psychology 89, no. 5: 747-763. DOI: $10.1037 / 0022-3514.89 .5 .747$

Public Policy and Institute of Management. 2006. Protų nutekéjimo' mažinimas ir protų susigrąžinimas (Decreasing brain drain and brain gain). URL : goo.gl/MaE4QD

Rajan, S. Irudaya, and Neha Wadhawan. 2014. Future diasporas? International student migration from India to the UK. Ministry of Overseas Indian Affairs, Research Unit on International Migration, Centre for Development Studies, Thiru- vananthapuram, IN.

Ramanauskaite, Egidija, and Rimas Vaisnys. 2015. To stay or not to stay: That is a question. European Scientific Journal 11, no. 3: 110-116.

Repeckiene, Ausra, Nida Kvedaraitė, and Renata Zvireliene. 2009. External and Internal Migration Insights in the Context of Globalization: Higher School Graduates' Attitude. Ekonomika ir Vadyba 14, 603-610.

Vaisnys, J. Rimas, Andrius Buivydas, and Egidija Ramanauskaite. 2010. Groups in theory and practice. Grupes ir aplinkos: Tarpdisciplininis mokslo darbu leidinys Groups and Environments: Interdisciplinary Research Studies 2: 23-55.

— This article does not have any appendix. - 